\title{
The asthma candidate gene NPSR1 mediates isoform specific downstream signalling
}

\author{
Christina Orsmark Pietras', Johanna Vendelin², Francesca Anedda 1,3, Sara Bruce', Mikael Adner ${ }^{4}$, Lilli Sundman², \\ Ville Pulkkinen ${ }^{2}$, Harri Alenius ${ }^{5}$, Mauro D'Amato ${ }^{1}$, Cilla Söderhäll ${ }^{1}$ and Juha Kere ${ }^{1,2,6^{*}}$
}

\begin{abstract}
Background: Neuropeptide S Receptor 1 (NPSR1, GPRA, GPR154) was first identified as an asthma candidate gene through positional cloning and has since been replicated as an asthma and allergy susceptibility gene in several independent association studies. In humans, NPSR1 encodes two G protein-coupled receptor variants, NPSR1-A and NPSR1-B, with unique intracellular C-termini. Both isoforms show distinct expression pattern in asthmatic airways. Although NPSR1-A has been extensively studied, functional differences and properties of NPSR1-B have not yet been clearly examined. Our objective was to investigate downstream signalling properties of NPSR1-B and functional differences between NPSR1-A and NPSR1-B.

Methods: HEK-293 cells transiently overexpressing NPSR1-A or NPSR1-B were stimulated with the ligand neuropeptide S (NPS) and downstream signalling effects were monitored by genome-scale affymetrix expressionarrays. The results were verified by NPS concentration-response and time series analysis using GRT-PCR, CAMP and $\mathrm{Ca}^{2+}$ assays, and CAMP/PKA, MAPK/JNK and MAPK/ERK pathway specific reporter assays.

Results: NPSR1-B signalled through the same pathways and regulated the same genes as NPSR1-A, but NPSR1-B yielded lower induction on effector genes than NPSR1-A, with one notable exception, CD69, a marker of regulatory T cells.

Conclusions: We conclude that NPSR1-B is regulating essentially identical set of genes as NPSR1-A, with few, but possibly important exceptions, and that NPSR1-A induces stronger signalling effects than NPSR1-B. Our findings suggest an isoform-specific link to pathogenetic processes in asthma and allergy.
\end{abstract}

\section{Background}

Neuropeptide S receptor 1 (NPSR1 also GPRA, GPR154) was first identified as an asthma susceptibility gene through positional cloning [1]. The genetic evidence was supported by significant single nucleotide polymorphism (SNP) and haplotype associations to asthma in three separate populations. To date, the association of NPSR1 to asthma and allergy has been replicated in seven independent populations [2-8]. Studies have also reported involvement of NPSR 1 in inflammatory disorders of skin and intestine $[9,10]$, neurally related traits such as sleep and circadian phenotypes [11] and anxiety [12].

\footnotetext{
* Correspondence: Juha.Kere@ki.se

'Department of Biosciences and Nutrition, Karolinska Institutet, Stockholm, Sweden

Full list of author information is available at the end of the article
}

NPSR1 is a 7-transmembrane G-protein coupled receptor (GPCR) phylogenetically related to other neuropeptide receptors such as neuropeptide Y (NPY), neurotensin and tachykinin receptors [13]. Upon stimulation by neuropeptide S (NPS), the natural ligand for NPSR1, downstream signalling has been shown to be mediated through intracellular coupling to Gaq and Gas $[14,15]$. Several NPSR1 splice variants have been identified but only two, NPSR1-A and NPSR1-B are effectively transported to the plasma membrane [16]. These two full-length splice variants differ in their 3' ends possessing alternate terminal exons $9 \mathrm{a}$ or $9 \mathrm{~b}$ (Figure 1a) which encodes distinct carboxy-terminal peptide chains (Figure 1b). The C-terminus is important for many stages of a GPCR protein lifespan and modifications can affect, e.g., transportation to the cell membrane, anchoring and downstream signalling [17]. Upon receptor activation, conformational changes reveal
C Biomed Central

() 2011 Pietras et al; licensee BioMed Central Ltd. This is an Open Access article distributed under the terms of the Creative Commons Attribution License (http://creativecommons.org/licenses/by/2.0), which permits unrestricted use, distribution, and reproduction in any medium, provided the original work is properly cited. 


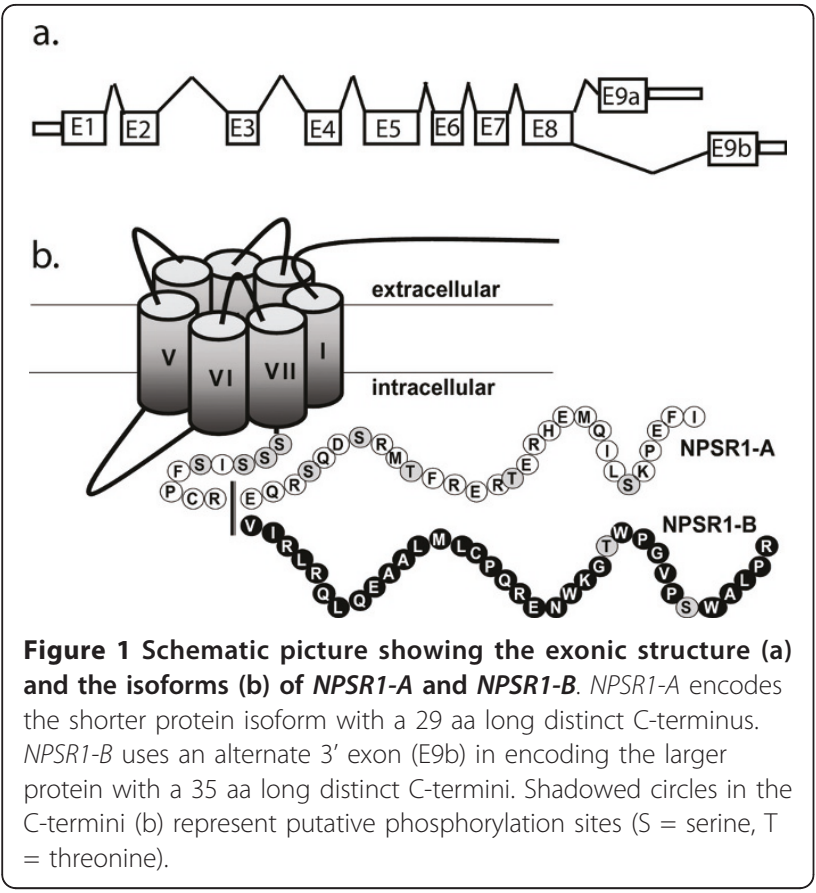

phosphorylation sites on the C-terminus. These sites are phosphorylated by $\mathrm{G}$ protein coupled receptor kinases (GRKs) and can bind GPCR activity regulating proteins, arrestins. Upon arrestin binding a receptor is targeted for internalization and recycling, redirected to G-protein independent signalling pathways such as mitogen-activated protein kinase (MAPK) pathway, or degraded [18].

The regulatory mechanisms of alternative splicing are not yet fully understood for NPSR1. However, it is clear that NPSR1 isoforms demonstrate distinct expression pattern in tissues and cells, with NPSR1-A generally showing a more ubiquitous expression, and that both isoforms have specific roles in inflammation, as previously shown for NPSR1-B, which is up regulated in asthmatic airways $[1,9,10,16,19]$. High total NPSR1 expression is found in murine brain [20] and it has been suggested that NPSR1 might contribute to an inflammatory phenotype by neurally mediated mechanisms $[21,22]$. It has been shown that the receptor potency for NPSR1 is dependent on the Ile107Asn isoform, where the NPSR1 Ile107 isoform gives a greater downstream response upon NPS stimulation than 107Asn [23-25]. In our study the NPSR1-A and -B constructs contain the more potent Ile107 isoform.

Even though these data suggest importance of both receptor signalling pathways, little is known about any functional disparity between these isoforms. In this study, we aimed to identify signal properties of NPSR1$B$ and clarify differences of downstream signalling between the NPSR1-A and NPSR1-B isoforms.

\section{Methods}

\section{Cell culture}

Human embryonic kidney cells (HEK-293) were cultured in MEM+GlutaMAX-1 medium (Gibco/Invitrogen) supplemented with $10 \%$ fetal calf serum (FCS) (Biosera), 1\% sodium pyruvate, $1 \%$ non-essential amino acids and $1 \%$ penicillin/streptomycin (Gibco/Invitrogen). Human epithelial lung carcinoma cells (A549) were cultured in F-12/D-MEM medium (1:1; Gibco/Invitrogen) supplemented with $10 \%$ FCS, L-glutamine and $1 \%$ penicillin/ streptomycin. Human neuroblastoma cells (SH-SY5Y) were cultured in MEM + GlutaMAX-1 medium supplemented with $10 \%$ FCS and 1\% penicillin/streptomycin. All cells were kept at $37^{\circ} \mathrm{C}$ in a humified $5 \% \mathrm{CO}_{2}$ incubator. The cells were transiently transfected (Lipofecta$\min ^{\mathrm{TM}} 2000$ Reagent, Invitrogen, Carlsbad, USA) with equal amounts of pCMV-NPSR1- $A$,- NPSR1-B (construction of the expression vectors has been described earlier) [16] or an empty pCMV vector control in a ratio of $1: 2$ (DNA:Lipofectamin). $24 \mathrm{~h}$ post transfection cells were stimulated with NPS (SFRNGVGTGMKKTSFQRAKS) (Sigma-Genosys LTD, Haverhill, UK or New England Peptide $^{\mathrm{TM}}$, Gardner, MA, USA).

RNA isolation and CDNA synthesis and quantitative realtime PCR (qRT-PCR)

Total cellular RNA was isolated with the RNAeasy Mini Kit (Qiagen, Hilden, Germany) and reverse transcription was done using the iScript ${ }^{\mathrm{TM}}$ cDNA synthesis kit (BioRad Laboratories, Hercules, CA, USA) or SuperScript ${ }^{\mathrm{TM}}$ First-Strand Synthesis System (Invitrogen, Carlsbad, USA) according to the manufacturer's protocol. All experiments were performed in biological duplicates or triplicates. qRT-PCR was performed using Fast SYBR ${ }^{\circledR}$ Green technology with hypoxanthine-guanine phosphoribosyl transferase (HPRT) or glyceraldehyde-3-phosphate dehydrogenase (GAPDH) as endogenous controls. Genespecific primers were designed using Primer3 software (for complete lists of all primer sequences please see Additional file 1, Table S1). The PCR assays were performed in a total volume of $10 \mu \mathrm{l}$, containing $2 \mathrm{ul}$ cDNA template, 5 ul Fast SYBR ${ }^{\circledR}$ Green PCR Master Mix (Applied Biosystems, Foster City, CA, USA) and $100 \mathrm{nM}$ of each primer. A 7500 Fast Real-Time PCR system (Applied Biosystems) was used according to manufacturer's instructions. A dissociation stage was added to confirm primer specificity. All assays were carried out in technical duplicates or triplicates. Relative quantification and calculation of the range of confidence was performed with the comparative $\Delta \Delta C \mathrm{~T}$ method [26]. Results are shown as relative expression compared to NPS stimulated empty vector control cells with error bars illustrating the standard error of the mean (SEM). 
The levels of total NPSR1 mRNA and isoform specific NPSR1-A and NPSR1-B mRNA were measured with qRT-PCR to control for equal isoform expression levels prior to any experiment on all transiently transfected cells (representative data shown Figure 2b).

\section{Fluorescence based quantification}

$24 \mathrm{~h}$ after transfection transiently NPSR1-A or -B overexpressing HEK-293 cells, stimulated with $1 \mu \mathrm{M}$ NPS or left untreated, were incubated $15 \mathrm{~min}$ in room temperature with mouse monoclonal antibodies specific for the $\mathrm{N}$-terminal NPSR1 peptide sequence TEGSFDSSGTG QTLDSSPVA (Quattromed, Tartu, Estonia). The incubated cells were washed with $\mathrm{PBS}+10 \%$ cell dissociation buffer, Hanks'-based (Invitrogen, Carlsbad, USA) followed by 15 min incubation of a FITC conjugated goat antimouse secondary antibody (Abcam, Cambridge, UK). The NPSR1 expression on the plasma membrane was analysed with BD FACSCalibur ${ }^{\mathrm{TM}}$. Data analysis was performed with the CellQuestPro software. Background correction was made for HEK-293 cells incubated with secondary antibody only. Prior to antibody incubation an aliquote of the cells were removed and lysed for NPSR1 RNA expression analysis.

\section{Expression-array sample preparation}

For the expression-array experiment, NPSR1-A, $-B$ or an empty pCMV vector was transiently transfected into HEK-293 cells and stimulated for $6 \mathrm{~h}$ with $2 \mu \mathrm{M}$ NPS. Total RNA (see section above) from each sample was used for cDNA synthesis according to the Affymetrix protocol. A total of 6 hybridizations (biological duplicates) and scannings (Affymetrix GeneChip Scanner 3000) were carried out using standard Affymetrix protocols for gene expression http://www.affymetrix.com with the HGU133plus2 array.
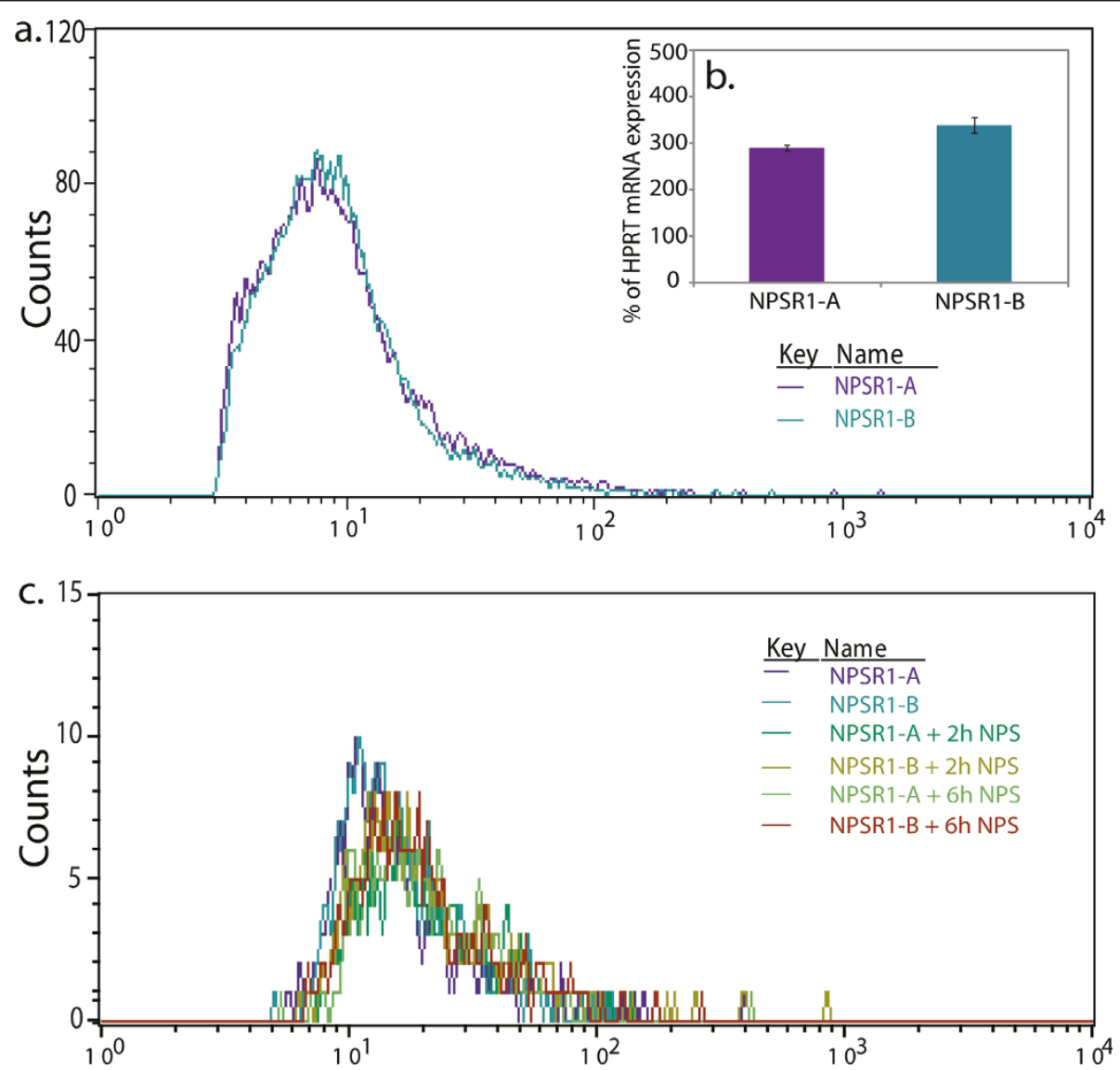

Figure 2 NPSR1 protein and mRNA expression in transient transfected HEK-293 cells. Transiently NPSR1-A or NPSR1-B overexpressing HEK293 cells, with or without NPS stimulation, were stained with an N-terminal monoclonal antibody together with a FITC conjugated secondary antibody, and the fluorescence intensity was measured. The histogram plot (a) shows that the intensity, representing the amount of receptors expressed on the cell membrane, and the transfection efficiency, represented by the number of counts, is the same between the two isoforms. From the same experiment NPSR1 mRNA expression was measured showing that the level of NPSR1-A and -B mRNA is similar between the respective overexpressing cells as well (b). Histogram plot (c) illustrates the intensity of the two isoforms after 2 and 6 hours of NPS stimulation. 


\section{Expression-array data analyses}

Experimental data were quality assessed, pre-processed, and analyzed as previously described [27] using the statistical software R http://www.R-project. org by implementing the packages Affy, limma, HGU133plus2 and kth [28-30]. A B-test (empirical Bayes shrinkage) was used to extract log-odds of differential expression (B-values). The B-statistics has an empirical distribution and cut-offs for differential expression have to be tailored for each experiment. Bvalue $>7$ was used as cut-off to derive a list of prioritized genes. The expression data is available at http:// www.ebi.ac.uk/arrayexpress/ with the ArrayExpress accession: E-MEXP-2782.

\section{NPS concentration-response and time series}

To refine concentration and time dependency transiently NPSR1-A, -B or empty pCMV vector overexpressing cells were treated either with 0.001, 0.01, $0.1,1$ or $10 \mu \mathrm{M}$ NPS for $6 \mathrm{~h}$ (concentration-response) or with $2 \mu \mathrm{M}$ NPS for $30 \mathrm{~min}, 1,2,4,6,12,24$ or 48 $\mathrm{h}$ (time-response). To verify the results in other cell types, A549 and SH-SY5Y transiently overexpressing NPSR1-A, -B or an empty pCMV vector were treated with $2 \mu \mathrm{M}$ NPS for $6 \mathrm{~h}$. mRNA expression was measured with qRT-PCR. Agonist concentration-effect curve data were fitted to the Hill equation using an iterative, least squares method (GraphPad Prism, San Diego, CA, U.S.A), to provide estimate $\mathrm{EC}_{50}$ (the agonist concentration that induces half-maximum effect) and presented as $-\log _{10}\left(\mathrm{pEC}_{50}\right)$ which is normally distributed.

\section{Measurements of intracellular CAMP accumulation and $\mathrm{Ca}^{2+}$ mobilization}

To assay cAMP accumulation, transiently NPSR1-A or -B overexpressing HEK-293 cells were $24 \mathrm{~h}$ after transfection incubated for $40 \mathrm{~min}$ with $200 \mu \mathrm{M}$ 3-isobutyl1-methylxanthine (Sigma-Aldrich, St. Louis, MO, USA), a nonspecific inhibitor of phosphodiesterases [31]. The cells were then stimulated with $0.001,0.01,0.1,1$ or 10 $\mu \mathrm{M}$ NPS for $20 \mathrm{~min}$, or left untreated, and prepared and stored at $-80^{\circ} \mathrm{C}$ until assayed in six replicas by the enzyme immunoassay (EIA; 581001, Cayman Chemical, Ann Arbor, MI, USA) according to the manufacturer's instructions. For the $\mathrm{Ca}^{2}$ assay, cells were seeded into 96-well plates, transiently transfected with NPSR1-A or -B and $24 \mathrm{~h}$ post-transfection the Fluo-4 NW calcium assay kit was used (F36205, Molecular Probes, Eugene, OR, USA) according to the manufacturer's instructions. The fluorescence intensity was measured before and after injection of $1 \mu \mathrm{M}$ NPS using the Fluostar Optima microplate reader (BMG Labtechnologies, Offenburg, Germany).

\section{Luciferase reporter assay}

Firefly-Luciferase reporter vectors for cAMP/PKA, MAPK/JNK and MAPK/ERK pathways were purchased from SABiosciences (Frederick, MD, USA), and used according to the manufacturer's instructions. Briefly, HEK-293 cells were transiently co-transfected with one of the above reporter vectors, a renilla-luciferase reporter vector for normalization ( $\mathrm{pRL}-\mathrm{TK}$ ) and either an empty pCMV vector, NPSR1-A or -NPSR1-B. Cells were stimulated for 6 hours with $1 \mu \mathrm{M}$ NPS (or left untreated). Luciferase assays were carried out with the Dual-Luciferase ${ }^{\circledR}$ Reporter Assay System (Promega, Madison, WI, USA) according to manufacturer's instructions. Firefly luciferase activities were normalized to the values obtained for renilla luciferase, and expressed as fold induction relative to cells unstimulated and transfected with the empty vector.

\section{Phosphorylation site-directed mutagenesis}

Phosphorylation site directed mutagenesis was performed on previously described pCMV-NPSR $1-A$ and -NPSR1-B constructs with the QuickChange ${ }^{\circledR}$ II-E sitedirected mutagenesis kit (Stratagene, La Jolla, CA, USA). Primers for each respective mutagenesis were designed using Stratagene's web-based QuickChange ${ }^{\circledR}$ primer design program http://www.stratagene.com/qcprimerdesigne (primer sequences are found in Additional file 1; Table S1). When designing the mutant constructs serine (S) and threonine ( $\mathrm{T}$ ) residues were exchanged for alanine (A) residues as follows: for the NPSR1-A unique $\mathrm{C}$-terminal; all three $\mathrm{S}$ sites and two $\mathrm{T}$ sites were exchanged for $\mathrm{A}(\mathrm{A} \Delta 5 \mathrm{p})$, the two most $\mathrm{N}$-terminal $\mathrm{S}$ residues and the most $\mathrm{N}$-terminal $\mathrm{T}$ residue $(\mathrm{A} \Delta 3 \mathrm{p})$ and the most $C$-terminal $\mathrm{T}$ and $\mathrm{S}$ residue $(\mathrm{A} \Delta 2 \mathrm{p})$, for the NPSR1-B unique $C$-terminal; the only $S$ and $T$ residue on the $-B$ isoform-tail were exchanged for $A(B \Delta 2 p)$ (for a schematic picture of the modified $\mathrm{C}$-termini please see Additional file 2, Figure S1). The modified inserts of all clones were sequence-verified. HEK-293 cells were transient transfected and stimulated with $2 \mu \mathrm{M}$ NPS for 1,6 and $24 \mathrm{~h}$, gene expression was monitored using qRT-PCR as described above.

\section{Statistical analysis}

Data are expressed as mean \pm SEM, unless stated otherwise. Student's $t$-test was used for parametric comparison between NPSR1-A and NPSR1-B, and $\mathrm{p} \leq 0.05$ was regarded as significant

\section{Results}

Protein and mRNA expression of NPSR1 overexpressing cells

Human embryonic kidney cells (HEK-293) express low levels of endogenous NPSR1 [27]. To assure that the 
NPSR1-A or -B transiently transfected HEK-293 cells expressed the isoforms in equal amounts, we measured the intensity of receptor protein on the plasma membrane with fluorescence based quantification, and mRNA with qRT-PCR (Figure 2). The FACS analysis showed that the transfection efficiency between the two isoforms was identical, with equal number of positive cell counts, and that the intensity of antibody bound receptor on each cell was similar both before and after NPS stimulation (Figure 2a, c). The mRNA levels between the NPSR1-A or NPSR1-B overexpressing cells was also comparable and in concordance with the protein expression (Figure $2 \mathrm{~b}$ ). The receptors mRNA expression levels were stable in the transient transfected cells up to seventy-two hours post-transfection (data not shown).

\section{Genome-scale affymetrix expression-arrays}

To investigate potential signalling differences between the two NPSR1 isoforms, we transiently transfected HEK-293 with NPSR1-A or NPSR1-B. We stimulated transfected cells and controls with NPS and monitored downstream signalling effects using the genome-scale Affymetrix HGU133plus2 expression-arrays. Biological duplicate samples were assayed and differentially regulated genes were identified by comparing NPS stimulated NPSR1-A or -B transfected cells against NPS stimulated pCMV-vector transfected cells. A stringent statistical threshold was used to derive a list of regulated genes $(B>7)$, prioritized based on likelihood of differential expression. Using this criterion, a total of 111 genes were identified as differentially expressed by NPSR1-A signalling (109 up regulated and two down regulated) and 55 genes by NPSR1-B signalling (all up regulated). 56 genes were found to be NPSR1-A specific but no genes were NPSR1-B specific. The 30 most differentially regulated genes with a more than three-fold up regulation by the NPSR1-A isoform and the corresponding fold change values for NPSR1-B are listed in Table 1. The most highly induced gene, CGA, was up regulated five times more by NPSR1-A compared to NPSR1-B and only one gene, CD69, was more induced by the $-\mathrm{B}$ isoform. Overall, the expression-array data suggested that NPS stimulation of NPSR1-A and -B isoforms up regulated the same genes but that NPSR1-A consistently yielded a higher induction of genes (Figure 3a).

\section{NPS concentration-response and time series analysis}

To verify the results from the expression-arrays and to investigate if the difference between NPSR1-A and -B signalling might depend on NPS concentration or dynamics, we performed concentration- and timeresponse experiments (Figure 3b). HEK-293 cells were transiently transfected with NPSR1-A, -B or an empty
pCMV-vector control and stimulated with either a fixed concentration of NPS $(2 \mu \mathrm{M})$ for 0.5 - $48 \mathrm{~h}$ or stimulated with a dilution series of NPS $(1 \mathrm{nM}-10 \mu \mathrm{M})$ for a fixed time of $6 \mathrm{~h}$. mRNA expression was measured by qRT-PCR for 11 genes from the expression-array experiment selected as follows; three genes with the highest relative fold change (CGA, CCL2O and IL8), four genes only induced by NPSR1-A (PCK1, SERPINB2, AREG and NTS), transcription factors (NR4A2, EGR1 and $F O S$ ), and $C D 69$ as the only gene more induced by NPSR1-B in the expression-array experiments.

The concentration-response experiments showed that overall, both receptor isoforms responded to increased NPS concentrations with a greater induction of genes, but with the NPSR1-A isoform consistently mediating a stronger response. However, stimulation of NPSR1-B mediated a stronger concentration-response on CD69 and no concentration-response on NTS. The $\mathrm{EC}_{50^{-}}$ values that could be estimated for the effect of NPS on NPSR1-A (all genes apart from CD69) and on NPSR1B (NR4A2, CGA, AREG, SERPINB2, CCL20 and PCK1) was generally close to $0.1 \mu \mathrm{M}$ with the exception of the effect on NR4A2 which was approximately $10 \mathrm{nM}$ for NPSR1-A (Table 2). In the NPS-NPSR1 time series study, genes could be categorised into early (PCK1, NR4A2, EGR1 and FOS), intermediate (CGA, AREG, NTS and CD69) and late (CCL20, IL8, SERPINB2) induced genes. The early induced genes consisted mainly of transcription factors. Upon induction of these genes, NPSR1-A mediated a stronger response than -B at the early peak of expression $(0.5-1 \mathrm{~h}$ post NPS stimulation) while at later time points the relative expression difference diminished and was similar to NPSR1-B induction of the same genes. The intermediate induced genes all peaked in expression 4-6 h post NPS stimulation. The relative expression for NPSR1-B induced genes was overall lower than -A, with one exception, CD69 and no expression was seen over time for NTS. The late induced genes peaked in relative expression 12-24 h post NPS stimulation and the response was always greater if induced by NPSR1-A. PCK1, SERPINB2 and AREG, which were exclusively up regulated upon NPSR1-A stimulation in the gene expression array experiment, were induced also by NPSR1-B in the time and concentration series experiment, although with low relative expression. The results verified and refined the expression-array data by demonstrating that most genes were induced by both isoforms but greater induction was obtained by NPSR1-A, as represented by CGA (Figure 3b: a, b). As exceptions NTS (Figure 3b: e, f) was not induced and CD69 (Figure 3b: c, d) was more strongly induced by NPSR1-B (data for the remaining genes tested are shown in Additional file 3, Figure S2). 
Table 1 The $>3$ fold change differentially expressed genes in the NPS-NPSR1-A and -B expression-array experiment.

\begin{tabular}{|c|c|c|c|c|}
\hline * & Gene Symbol & Gene name & $\begin{array}{l}\text { NPS-NPSR1-A Vs } \\
\text { NPS-empty vector }\end{array}$ & $\begin{array}{l}\text { NPS-NPSR1-BVs } \\
\text { NPS-empty vector }\end{array}$ \\
\hline 1 & CGA & GLYCOPROTEIN HORMONES. ALPHA POLYPEPTIDE & 63.0 & 11.2 \\
\hline 2 & CCL20 & CHEMOKINE (C-C MOTIF) LIGAND 20 & 21.7 & 10.2 \\
\hline 3 & IL8 & INTERLEUKIN 8 & 12.5 & 7.8 \\
\hline 4 & PCK1 & PHOSPHOENOLPYRUVATE CARBOXYKINASE 1 (SOLUBLE) & 11.4 & - \\
\hline 5 & NR4A2 & NUCLEAR RECEPTOR SUBFAMILY 4. GROUP A. MEMBER 2 & 10.5 & 4.1 \\
\hline 6 & NR4A3 & NUCLEAR RECEPTOR SUBFAMILY 4. GROUP A. MEMBER 3 & 8.4 & 4.4 \\
\hline 7 & C8orf4 & CHROMOSOME 8 OPEN READING FRAME 4 & 7.4 & 4.6 \\
\hline 8 & SERPINB2 & SERPIN PEPTIDASE INHIBITOR. CLADE B (OVALBUMIN). MEMBER 2 & 6.9 & - \\
\hline 9 & CTGF & CONNECTIVE TISSUE GROWTH FACTOR & 6.3 & 4.5 \\
\hline 10 & CXCL2 & CHEMOKINE (C-X-C MOTIF) LIGAND 2 & 6.1 & 3.6 \\
\hline 11 & TAC1 & TACHYKININ. PRECURSOR 1 & 5.9 & 2.7 \\
\hline 12 & EGR3 & EARLY GROWTH RESPONSE 3 & 4.9 & 4.4 \\
\hline 13 & AREG & AMPHIREGULIN (SCHWANNOMA-DERIVED GROWTH FACTOR) & 4.6 & - \\
\hline 14 & FOSB & FBJ MURINE OSTEOSARCOMA VIRAL ONCOGENE HOMOLOG B & 4.6 & 3.1 \\
\hline 15 & CYR61 & CYSTEINE-RICH. ANGIOGENIC INDUCER. 61 & 4.6 & 2.9 \\
\hline 16 & INHBA & INHIBIN. BETA A (ACTIVIN A. ACTIVIN AB ALPHA POLYPEPTIDE) & 4.6 & 2.5 \\
\hline 17 & EGR1 & EARLY GROWTH RESPONSE 1 & 4.3 & 3.9 \\
\hline 18 & FOS & V-FOS FBJ MURINE OSTEOSARCOMA VIRAL ONCOGENE HOMOLOG & 4.3 & 3.1 \\
\hline 19 & MAFF & V-MAF MUSCULOAPONEUROTIC FIBROSARCOMA ONCOGENE HOMOLOG F (AVIAN) & 4.2 & 3.6 \\
\hline 20 & NTS & NEUROTENSIN & 4.1 & \\
\hline 21 & TM4SF1 & TRANSMEMBRANE 4 L SIX FAMILY MEMBER 1 & 4.0 & - \\
\hline 22 & SNAP25 & SYNAPTOSOMAL-ASSOCIATED PROTEIN. 25 KDA & 4.0 & - \\
\hline 23 & CD69 & CD69 ANTIGEN (P60. EARLY T-CELL ACTIVATION ANTIGEN) & 3.8 & 4.6 \\
\hline 24 & MMP10 & MATRIX METALLOPEPTIDASE 10 (STROMELYSIN 2) & 3.6 & - \\
\hline 25 & STC1 & STANNIOCALCIN 1 & 3.6 & - \\
\hline 26 & ELL2 & ELONGATION FACTOR. RNA POLYMERASE II. 2 & 3.6 & 2.2 \\
\hline 27 & LOC387763 & HYPOTHETICAL LOC387763 & 3.5 & 2.0 \\
\hline 28 & GEM & GTP BINDING PROTEIN OVEREXPRESSED IN SKELETAL MUSCLE & 3.4 & 1.9 \\
\hline 29 & BIRC3 & BACULOVIRAL IAP REPEAT-CONTAINING 3 & 3.3 & - \\
\hline 30 & PTX3 & PENTRAXIN-RELATED GENE. RAPIDLY INDUCED BY IL-1 BETA & 3.2 & 2.8 \\
\hline
\end{tabular}

* Numbers corresponds to position in Figure 3.

To investigate if differences in regulation of gene expression between NPSR1-A and NPSR1-B could be seen in other cell types, we transiently transfected two additional cell lines, human epithelial lung carcinom (A549) and human neuroblastoma (SH-SY5Y). The same eleven genes selected for the concentration/timeresponse study were analysed (CGA, CCL20, IL8, PCK1, SERPINB2, AREG, NTS, NR4A2, EGR1, FOS, and $C D 69)$. Although most genes differentially expressed in the HEK-293 cells were altered in these cell lines as well (no expression was however detected for NR4A2, SERPINB2 or AREG in SH-SY5Y cells and SERPINB2 in A549 cells), the effect of NPS stimulation on relative gene expression was weaker compared to NPSR1-A or -B overexpressing HEK-293 cells. However, similarly to HEK-293 cells, genes regulated by NPSR1-B were consistently less altered compared to NPSR1-A in both cell lines (Figure 4a, b).

\section{CAMP and $\mathrm{Ca}^{2+}$ assays}

Downstream response of cAMP and $\mathrm{Ca}^{2+}$ was measured before and after NPS stimulation of NPSR1-A and -B transiently overexpressing HEK-293 cells. The concentration-response curve for the cAMP assay illustrated that both - A and - B uses cAMP as a second messenger but the response generated by NPSR1-A was much stronger than $-\mathrm{B}$ (Figure $5 \mathrm{a}$ ). The $\mathrm{EC}_{50}$-values for NPSinduced CAMP formation for both NPSR1-A and NPSR1-B were close to $5 \mathrm{nM}$, respectively (Table 2). In the $\mathrm{Ca}^{2+}$ experiment we looked at the release of $\mathrm{Ca}^{2+}$, before and after injection of $1 \mu \mathrm{M}$ NPS to the cells. Here we could also see that the increase of intracellular 


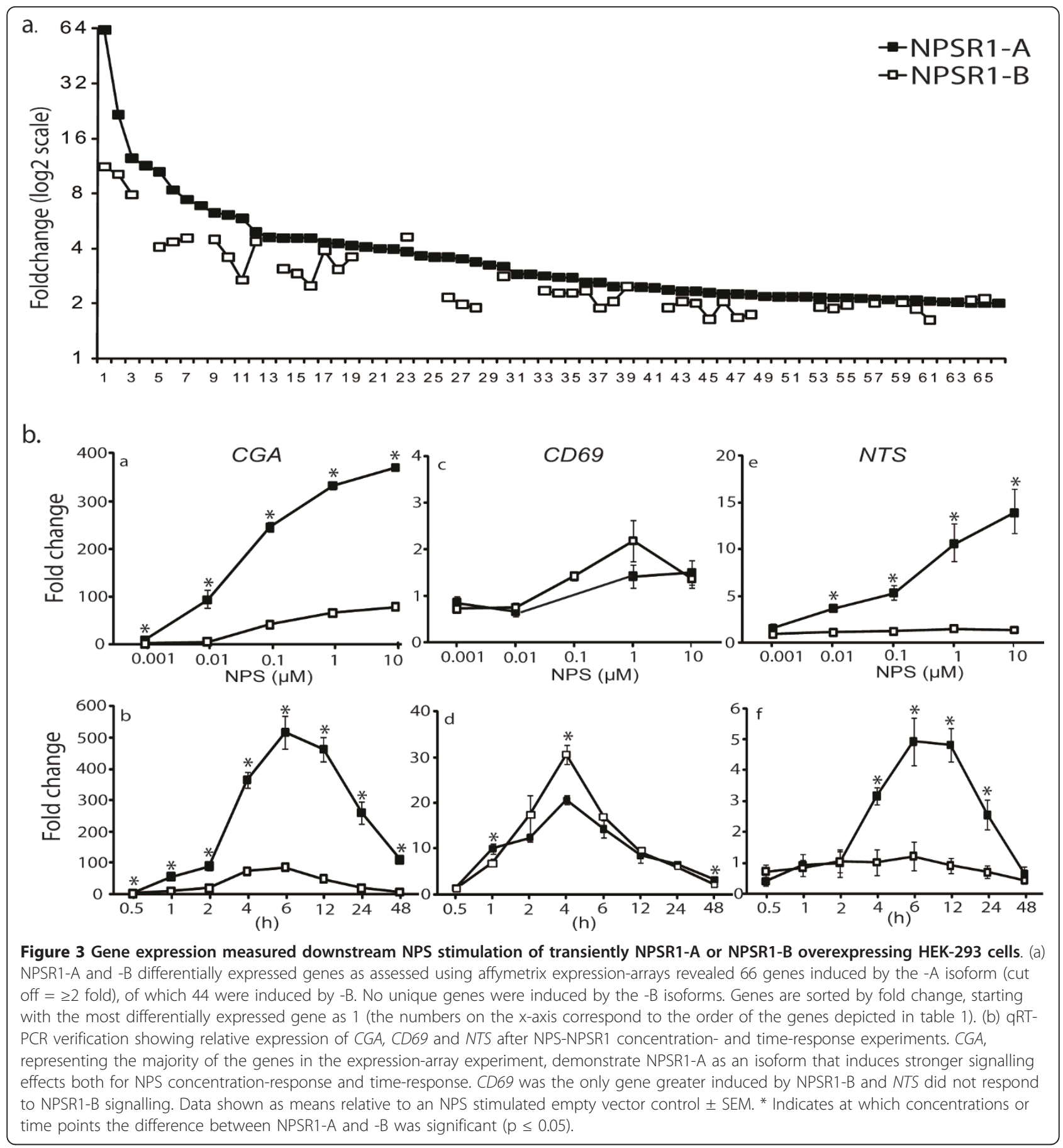

$\mathrm{Ca}^{2+}$, in response to NPS stimulation, was higher in NPSR1-A than in -B (Figure 5b).

\section{Reporter assays}

To further investigate differences seen in gene regulation between NPSR1-A and NPSR1-B, we studied activation of transcription factors representing three signalling pathways; cAMP/PKA, MAPK/JNK and MAPK/ERK. In these experiments, HEK-293 cells were transiently transfected with NPSR1-A, -B or empty pCMV vector together with an inducible transcription factor responsive luciferase construct. Cells were stimulated with NPS $(1 \mu \mathrm{M})$ for $6 \mathrm{~h}$ and assayed for the relative luciferase activity. We observed that NPSR1-A induced a stronger response than NPSR1-B of the cAMP/PKA pathway (six fold) and one and a half (ERK) to two fold stronger 
Table 2 NPS concentration-response curve analysis on NPSR1-A or -B overexpressing HEK-293 cells.

\begin{tabular}{lcc}
\hline pEC $_{\text {50 }}$ values & NPSR1-A & NPSR1-B \\
\hline NR4A2 & $8.10 \pm 0.06$ & $7.08 \pm 0.27$ \\
EGR1 & $7.14 \pm 0.27$ & n.d. \\
FOS & $7.27 \pm 0.21$ & n.d. \\
CGA & $7.34 \pm 0.05$ & $7.00 \pm 0.06$ \\
AREG & $6.63 \pm 0.31$ & $6.77 \pm 0.83$ \\
NTS & $7.06 \pm 0.23$ & n.d. \\
IL8 & $7.35 \pm 0.14$ & n.d. \\
SERPINB2 & $7.62 \pm 2.93$ & $6.90 \pm 0.61$ \\
CCL20 & $6.79 \pm 1.67$ & $7.00 \pm 0.08$ \\
CD69 & n.d. & n.d. \\
PCK1 & $6.79 \pm 0.07$ & $7.05 \pm 0.15$ \\
& & \\
CAMP & $8.35 \pm 0.17$ & $8.41 \pm 0.28$ \\
\hline
\end{tabular}

The $\mathrm{EC}_{50}$ value (the agonist concentration that induces half-maximum effect) is presented as $-\log _{10}\left(\mathrm{pEC} \mathrm{C}_{50}\right)$. Data are expressed as mean $\pm \mathrm{SEM}$. When a concentration-response curve not fitted to the Hill equation the $\mathrm{pEC}_{50}$ was not determined (n.d.).

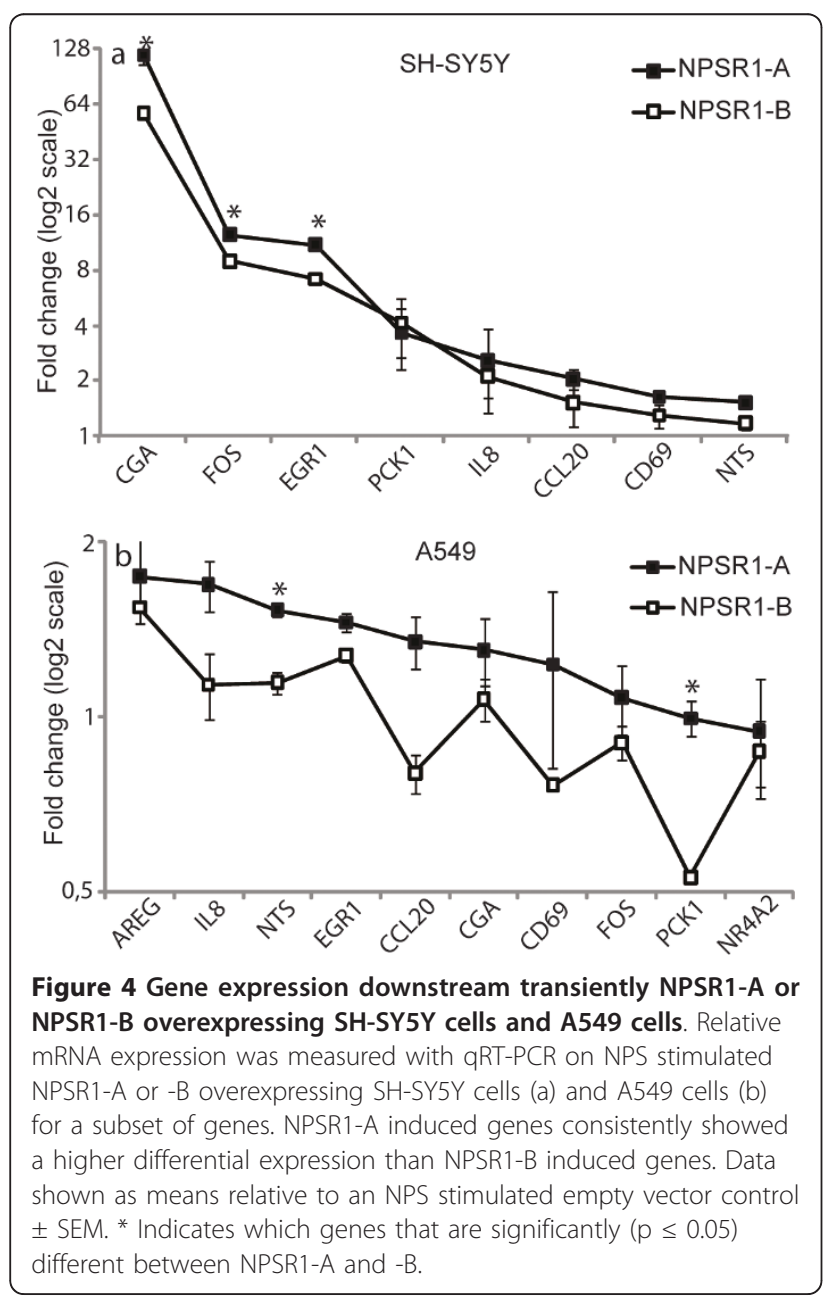

(JNK) activator of the MAPK pathways (Figure 6). The results further supported the expression-array experiment and illustrated that NPSR1-A yields a stronger activation of transcription factor complexes.

\section{Phosphorylation site-directed mutagenesis}

To dissect the mechanisms of different regulatory effects between the NPSR1-A and -B isoforms, we performed phosphorylation site-directed mutagenesis. The NPSR1$A$ and -B isoforms possess distinct C-termini which, together with the third intracellular loop, contain phosphorylation sites potentially important for arrestin docking [18]. Phosphorylation occurs predominantly on serine $(\mathrm{S})$ and threonine $(\mathrm{T})$ residues [32] and, as illustrated in Figure 1b, NPSR1-A carries five unique Cterminal phosphorylation sites, whereas NPSR1-B only two. We generated NPSR1-A constructs with all five unique phosphorylation sites in the C-terminal mutated to alanine (A $\Delta 5 \mathrm{p}$ ), three sites mutated (A $\Delta 3 \mathrm{p})$ and two sites mutated $(\mathrm{A} \triangle 2 \mathrm{p})$ and NPSR1-B constructs with the only two unique sites mutated (B $\Delta 2 \mathrm{p}$ ) (Additional file 2, Figure S1). HEK-293 cells were transiently transfected with the mutant constructs or the wild type pCMVNPSR1-A or NPSR1-B, stimulated with NPS for $6 \mathrm{~h}$ and the downstream expression of a subset of genes were measured with qRT-PCR. The results showed that the removal of phosphorylation sites did not have any effect on downstream gene expression (representative gene shown in Figure 7), suggesting that the significant differential effect between NPSR1-A and -B involves mechanism(s) distinct from simple phosphorylation differences.

\section{Discussion}

The increasing number of positive association studies supports the concept that NPSR 1 is mechanistically involved in asthma and allergy [1-8,33-35], and also in other diseases [9-12,36]. It is therefore highly important to understand its functions in more detail. We have previously identified downstream target genes for NPSNPSR1-A signalling using stably NPSR1-A overexpressing HEK-293 cells, and found that many of the up regulated genes are involved in cellular processes such as cell proliferation, morphogenesis and immune responses [27]. Furthermore, we have observed that out of seven splice variants only the full-length variants NPSR1-A and NPSR1-B are transported to the plasmamembrane in transiently transfected COS-1 cells [16], which we can in this study show for NPSR1-A and -B in transiently transfected HEK-293 cells as well. The two NPSR1 isoforms differ in the C-terminal where the last 29 amino acids are unique for NPSR1-A, and the last 35 for NPSR1-B (Figure 1b). Although there is low endogenous expression of GPCRs in most native tissues and cells, generally, NPSR1-A is expressed at a higher 

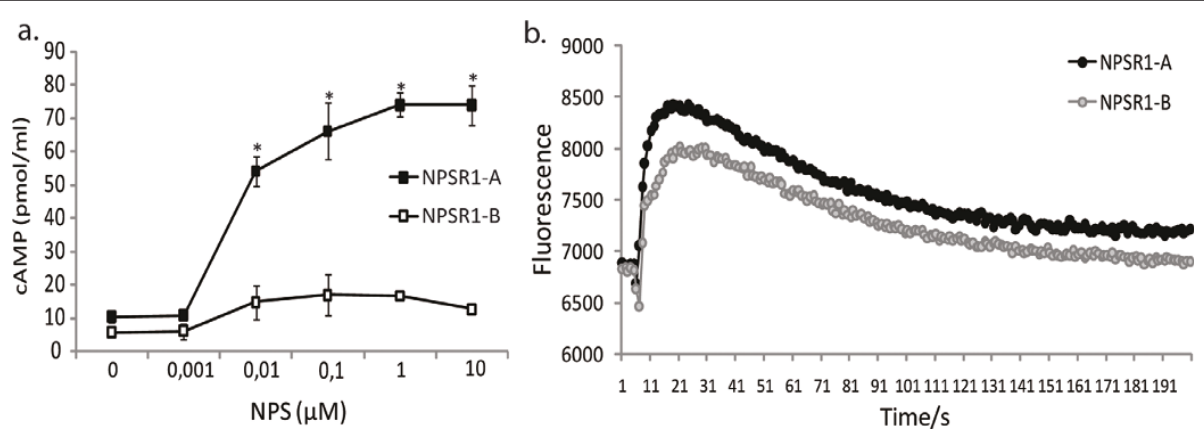

Figure 5 CAMP and $\mathrm{Ca}^{2+}$ response downstream NPS-NPSR1-A and -B signalling. Intracellular second messenger response was measured on transiently NPSR1-A or -B overexpressing HEK293 cells stimulated with NPS. The CAMP response (a) was measured in a concentration-response way showing a greater increase of CAMP in NPS-NPSR1-A stimulated cells. In the $\mathrm{Ca}^{2+}$ experiment (b) a fixed dose of $1 \mu \mathrm{M}$ NPS was used and intracellular $\mathrm{Ca}^{2+}$ accumulation was measured before and after injection ( $\left.\mathrm{t}=5 \mathrm{~s}\right)$ of NPS. The $\mathrm{Ca}^{2+}$ also illustrates an increased response in the NPSR1-A overexpressing cells compared to NPSR1-B. CAMP data is shown as mean \pm SEM and * indicates significant $(p<0.05)$ difference between NPSR1-A and -B. The $\mathrm{Ca}^{2+}$ plot illustrates data from a representative experiment.

level when compared with NPSR1-B and has a more ubiquitous expression pattern. However, in some inflammatory conditions, both isoforms are up regulated and in some cases, e.g., in smooth muscle cells and epithelial cells in asthmatic airways, NPSR1-B may be even more abundant than -A $[1,9,10]$. In inflammatory cells, such as neutrophils, monocytes and eosinophils, both NPSR1$A$ and -B are up regulated, but NPSR1-B is more abundant in, e.g., CD4+ T cells $[9,19]$. Monocytic cell lines stimulated with pro-inflammatory stimuli, such as TNF $\alpha$ and IFN $\gamma$, generated elevated NPSR1 mRNA levels [10]. These data not only point towards an important role for NPSR1 in inflammation but also to more specific and perhaps distinct roles for NPSR1-A and -B.

Since functional differences and properties of NPSR1$B$ have not yet been clearly examined our primary aim was to investigate this, using a cell line, HEK-293, that would make the results interpretable in the background of previous relevant studies on NPSR1. When using genome-scale expression arrays to investigate downstream target genes of NPS stimulated HEK-293 cells, transiently transfected with NPSR1-A or NPSR1-B, we found that target gene expression was regulated in an isoform-specific manner. We found the same set of genes to be induced, but NPSR1-A almost exclusively yielded a stronger induction than NPSR1-B, despite equal expression of receptor protein on the plasma membrane (Figure 2a, c). Out of the NPSR1-A induced genes with a more than two fold differential expression, half displayed no significant induction by the NPSR1-B isoform. However, these genes were frequently found to be regulated by the B isoform as well, when looking at genes less than two fold differentially expressed. Of the genes up regulated more than two fold, by both NPSR1-

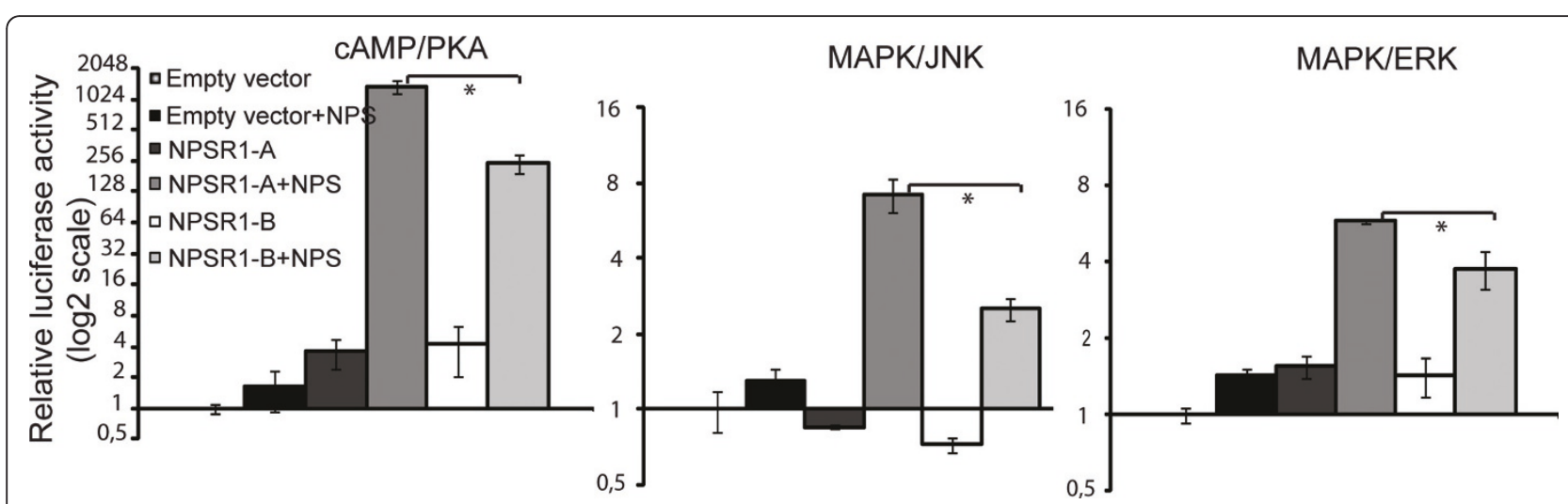

Figure 6 Reporter assays on NPS-NPSR1 isoform specific activation of CAMP/PKA, MAPK/JNK and MAPK/ERK pathways. NPS stimulated NPSR1-A or -B overexpressing HEK-293 cells were assayed for transcription factor complex activation of pathways related to GPCR signalling. The results demonstrate that NPSR1-A is a more efficient activator, with a more than 6 fold change for the CAMP/PKA pathway. Data shown as means relative to an empty vector control \pm SEM. ${ }^{*}$ Indicates significant $(p<0.05)$ difference between NPSR1-A and $-B$. 


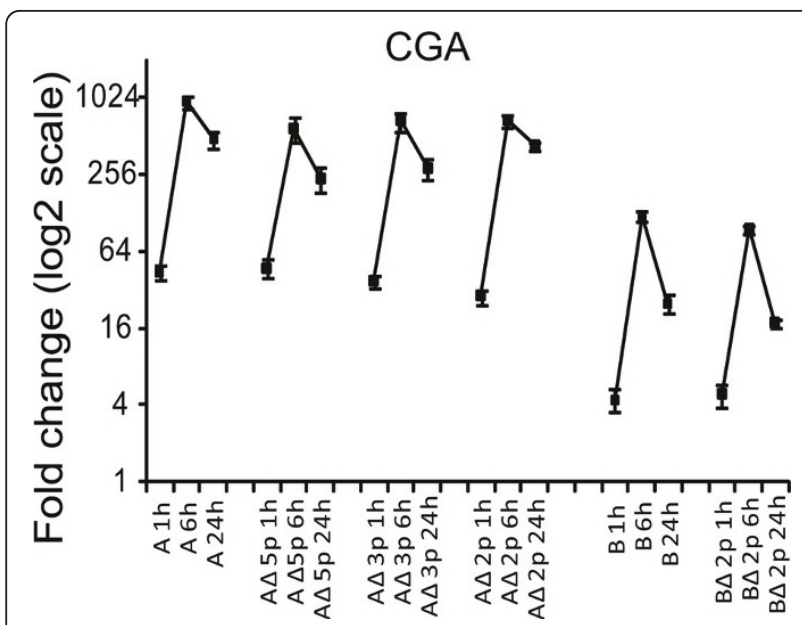

Figure 7 Phosphorylation site-directed mutagenesis of NPSR1A and NPSR1-B C-termini. Relative CGA mRNA expression after 1, 6 and 24 h NPS stimulation of HEK-293 cells overexpressing NPSR1$A$ or $-B$ containing phosphorylation site mutations in the C-termini. From left to right: NPSR1-A,-A $\triangle 5 p,-A \triangle 3 p,-A \triangle 2 p$, NPSRI-B and -B $\triangle 2 p$. Expression shown as means relative to an NPS stimulated empty vector control \pm SEM.

A and $-\mathrm{B}$, a striking majority showed stronger induction by -A. Most of the genes mediated by the NPSR1-A isoform were the same as in our previous expression-array experiment, using NPS stimulated stably NPSR1-A overexpressing HEK-293 cells [27]. However, some new downstream target genes were identified in the present study. These include CCL20, CD69 and PTX3.

Since genes can be early or late responder genes, and our expression-array data only show a cross-section of genes expressed at six hours, we investigated if NPSR1-A and -B required different duration of NPS stimulation to activate gene expression. In the same manner, we also tested if the concentration-response effect differed between the isoforms. The results showed that NPS-NPSR1 regulated gene expression in a time- and concentration-dependent manner and that NPSR1-A, even though the $\mathrm{EC}_{50}$-values were similar between the isoforms, was overall a stronger inducer of gene expression. This supports the fact of a clear difference in signalling properties between NPSR1-A and $-\mathrm{B}$. Out of the 11 genes investigated by qRT-PCR, we only found one gene specifically regulated by NPSR1-A, Neurotensin (NTS), and one gene showing greater induction by NPSR1-B, CD69 antigen (CD69) (Figure 3). NTS is a neuropeptide widely distributed throughout the central nervous system and it has been linked both to regulation of circadian rhythms [37] and IBD-related oncogenesis [38]. CD69 is an early activation marker of regulatory $\mathrm{T}$ cells (Tregs). Tregs are important in monitoring the balance between $\mathrm{T}$ helper type $2\left(\mathrm{~T}_{\mathrm{H}} 2\right)$ cells and $\mathrm{T}_{\mathrm{H}} 1$ cells, important for asthma and other inflammatory disorders [39]. These observations connect well to the genetic associations reported for NPSR1. Recently, CD69 was reported to specifically control the pathogenesis of allergic airway inflammation [40], and over expression of the NPSR1$B$ isoform in asthmatic airways [1] might thus drive this pathway toward allergic inflammation.

The majority of protein-coding genes in the human genome are known to undergo alternative splicing [41] but it is still not fully understood how the cell- and tissue-specific splicing is regulated [42]. Expression profiling of NPSR1-A and NPSR1-B demonstrates that the isoforms are differentially expressed in tissues and cells, suggesting tissue-specific regulation of alternative splicing $[1,9,16,19]$. Hence, we investigated NPS-NPSR1-A and -B signalling in lung cells (A549) and neuronal cells (SH-SY5Y). We identified some differences between cell lines in terms of which genes are regulated which might be due to different gene regulatory mechanisms that are active in different cell types. However, we conclude that although the induction of these selected genes is not of the same magnitude as in HEK-293 cells, NPSR1-A is the stronger activator also in A549 and SH-SY5Ycells. In these cell lines we could not find specific genes regulated by one isoform alone.

To further study NPS-NPSR1 isoform-specific downstream activity, we investigated intracellular cAMP accumulation and $\mathrm{Ca}^{2+}$ release from each respective isoform. The response generated by NPSR1-A was clearly higher for both second messengers. We also looked at activation of downstream transcription factor complexes. Upon activation of GPCRs the receptor signals both through the traditional G-proteins, but also through alternative pathways such as mitogen-activated protein kinases (MAPKs) [18]. The results illustrated that both NPSR1-A and -B induced transcription factors representing CAMP/PKA and MAPK pathways, but that signalling through NPSR1-A gave a stronger response. These data confirmed our expression-array findings and suggested that the difference in signalling is already seen at a second-messenger and transcription factor level.

Upon stimulation of GPCRs, conformational changes of the receptor activate $G$ proteins. Recent studies have shown that the $\mathrm{C}$-terminal of the receptor is most likely not involved in the activation, but rather regulates the selectivity towards which $G$ protein is utilized [43]. Previous studies demonstrate that NPS-NPSR1-A signals through Gaq and Gas [14,15] and since activation of NPSR1-A and -B induces the same genes, it is likely that they select the same type of G-proteins. After activation, the GPCRs are rapidly desensitized by phosphorylation and arrestin binding. These events predominantly occur on serine $(\mathrm{S})$ and threonine $(\mathrm{T})$ residues within the $\mathrm{C}$-terminal and the third intracellular loop 
[32]. After desensitization, the receptor is internalized and targeted for degradation, redirected signalling through G-protein independent pathways (e.g. MAPK) or recycled back to the membrane [18]. Previous studies have shown that phosphorylation site-directed mutations at the C-terminal of GPCRs severely impaired both the ability to undergo phosphorylation and to recruit arrestin $[44,45]$. It has also been demonstrated that conformational changes that improve $\mathrm{C}$-terminal phosphorylation also enhances arrestin binding and endocytosis [46]. As depicted in Figure 1b, NPSR1-A contains more than twice as many unique phosphorylation sites as NPSR1-B. This opens up for the possibility that the -A isoform undergoes a faster turnover and hence is able to affect downstream gene expression in a more efficient way. To test this hypothesis we performed phosphorylation site-directed mutagenesis on both NPSR1-A and -B, replacing all or a subset of potential phosphorylation sites with alanine. The results revealed however that the number of phosphorylation sites in the NPSR1-A and NPSR1-B C-terminal did not seem to affect the difference in downstream gene regulation observed between the isoforms, even though minor effects were seen within each isoform group. The mechanisms behind isoform specific gene regulation will need further investigation.

\section{Conclusions}

Several studies point towards an important role for NPSR1 in asthma and allergy, and moreover an explicit role for the $-\mathrm{A}$ and $-\mathrm{B}$ isoforms. Prior studies have not revealed any significantly altered second messenger response between NPSR1-A and NPSR1-B or investigated differences in downstream gene expression $[16,23]$. From this study we conclude that signalling of NPS-NPSR1-A and -B affect the same pathways but in an isoform specific manner, identifying NPSR1-A as a receptor with stronger signalling effects with few, but possibly important exceptions (such as CD69). In addition, we examined unique phosphorylation sites in the C-termini as a plausible explanation for discrepancy, but our data indicated that the differential effect was more complicated than a simple phosphorylation target difference. Our results suggest an isoform-specific link to pathogenetic processes in allergic airways.

\section{Additional material}

Additional file 1: Table S1. Primers sequences. Sequences for all primers used for qRT-PCR.

Additional file 2: Figure S1. Schematic picture of the C-terminal tail of NPSR1-A and -B illustrating the phosphorylation site-directed mutagenesis constructs. Three different constructs were designed for NPSR1-A, $A \triangle 5 p, A \triangle 3 p, A \triangle 2 p$, and one for NPSR1-B; $B \triangle 2 p$ exchanging serine $(S)$ or threonine $(T)$ sites for alanine $(A)$.
Additional file 3: Figure S2. NPS-NPSR1 concentration- and timeresponse. Relative expression monitored by qRT-PCR downstream NPSR1-A or -B overexpressing HEK-293 cells for NPS dose- $(6 \mathrm{~h}$ stimulation) and time-response ( $2 \mu \mathrm{M}$ NPS), for eight representative genes. Data shown as relative to an NPS stimulated empty vector control. * Indicates at which concentrations or time points the difference between NPSR1-A and -B was significant ( $p \leq 0.05$ ).

\section{Acknowledgements and Funding}

This work was supported by the Swedish Research Council, the Chronic Inflammation Diagnosis and Therapy consortium, Sigrid Jusélius Foundation, Päivikki and Sakari Sohlberg Foundation, Novo Nordisk Foundation, Johnson \& Johnson and the Academy of Finland (J.K.), Swedish Society of Medical Research (C.S.), and The Ruth and Richard Juhlin's Foundation and the Professor Nanna Svartz Foundation (M.D'A.) We would also like to thank Center for cell analysis (CCA) at Karolinska University Hospital, the Affymetrix core facility at Novum, Bioinformatics and Expression Analysis (BEA), which is supported by the board of research at the Karolinska Institute and the research committee at the Karolinska Hospital, and Riitta Känkäinen and Ingrid Delin for technical assistance.

\section{Author details}

'Department of Biosciences and Nutrition, Karolinska Institutet, Stockholm, Sweden. ${ }^{2}$ Department of Medical Genetics, University of Helsinki and Folkhälsan Institute of Genetics, Helsinki, Finland. ${ }^{3}$ Istituto di Neurogenetica e Neurofarmacologica, Consiglio Nazionale della Ricerche, Monserrato, Italy. ${ }^{4}$ The National Institute of Environmental Medicine, Division of Physiology, Karolinska Institutet, Stockholm, Sweden. ${ }^{5}$ Unit of Excellence for

Immunotoxicology, Finnish Institute of Occupational Health, Helsinki, Finland. ${ }^{6}$ Science for Life Laboratory, Stockholm, Sweden.

\section{Authors' contributions}

COP, JV, MDA, JK conceived and designed the experiments. COP, JV, FA, CS performed the experiments. COP, JV, SB, MA, MDA, CS analyzed the data. LS, $V P, H A$, JK contributed reagents/materials/analysis tools. COP wrote the paper. JV, CS, JK revised the manuscript for important intellectual content. All authors read and approved the final manuscript.

\section{Competing interests}

The authors declare that they have no competing interests.

Received: 18 October 2010 Accepted: 27 June 2011

Published: 27 June 2011

\section{References}

1. Laitinen T, Polvi A, Rydman P, Vendelin J, Pulkkinen V, Salmikangas P, Makela S, Rehn M, Pirskanen A, Rautanen A, Zucchelli M, Gullsten H, Leino M, Alenius H, Petays T, Haahtela T, Laitinen A, Laprise C, Hudson TJ, Laitinen LA, Kere J: Characterization of a common susceptibility locus for asthma-related traits. Science 2004, 304(5668):300-304.

2. Hersh CP, Raby BA, Soto-Quiros ME, Murphy AJ, Avila L, Lasky-Su J, Sylvia JS Klanderman BJ, Lange C, Weiss ST, Celedon JC: Comprehensive Testing of Positionally Cloned Asthma Genes in Two Populations. Am J Respir Crit Care Med 2007, 176:849-857.

3. Feng $Y$, Hong $X$, Wang $L$, Jiang $S$, Chen $C$, Wang B, Yang J, Fang $Z$, Zang $T$, $\mathrm{Xu}$ X: G protein-coupled receptor 154 gene polymorphism is associated with airway hyperresponsiveness to methacholine in a Chinese population. J Allergy Clin Immunol 2006, 117(3):612-617.

4. Melen E, Bruce S, Doekes G, Kabesch M, Laitinen T, Lauener R, Lindgren CM, Riedler J, Scheynius A, van Hage-Hamsten M, Kere J, Pershagen G, Wickman M, Nyberg F: Haplotypes of G protein-coupled receptor 154 are associated with childhood allergy and asthma. Am J Respir Crit Care Med 2005, 171(10):1089-1095.

5. Kormann MS, Carr D, Klopp N, Illig T, Leupold W, Fritzsch C, Weiland SK, von Mutius E, Kabesch M: G-Protein-coupled receptor polymorphisms are associated with asthma in a large German population. Am J Respir Crit Care Med 2005, 171(12):1358-1362. 
6. Daley D, Lemire M, Akhabir L, Chan-Yeung M, He JQ, McDonald T, Sandford A, Stefanowicz D, Tripp B, Zamar D, Bosse Y, Ferretti V, Montpetit A, Tessier MC, Becker A, Kozyrskyj AL, Beilby J, McCaskie PA Musk B, Warrington N, James A, Laprise C, Palmer L, Pare PD, Hudson TJ: Analyses of associations with asthma in four asthma population samples from Canada and Australia. Hum Genet 2009, 125(4):445-459.

7. Castro-Giner F, de Cid R, Gonzalez JR, Jarvis D, Heinrich J, Janson C, Omenaas ER, Matheson MC, Pin I, Anto JM, Wjst M, Estivill X, Kogevinas M: Positionally cloned genes and age-specific effects in asthma and atopy: an international population-based cohort study (ECRHS). Thorax 2010, 65:124-131.

8. Malerba G, Lindgren CM, Xumerle L, Kiviluoma P, Trabetti E, Laitinen T, Galavotti R, Pescollderungg L, Boner AL, Kere J, Pignatti PF: Chromosome 7p linkage and GPR154 gene association in Italian families with allergic asthma. Clin Exp Allergy 2007, 37(1):83-89.

9. D'Amato M, Bruce S, Bresso F, Zucchelli M, Ezer S, Pulkkinen V, Lindgren C, Astegiano M, Rizzetto M, Gionchetti P, Riegler G, Sostegni R, Daperno M, D'Alfonso S, Momigliano-Richiardi P, Torkvist L, Puolakkainen P, Lappalainen M, Paavola-Sakki P, Halme L, Farkkila M, Turunen U, Kontula K, Lofberg R, Pettersson S, Kere J: Neuropeptide s receptor 1 gene polymorphism is associated with susceptibility to inflammatory bowel disease. Gastroenterology 2007, 133(3):808-817.

10. Sundman L, Saarialho-Kere U, Vendelin J, Lindfors K, Assadi G, Kaukinen K, Westerholm-Ormio M, Savilahti E, Maki M, Alenius H, d'amato M, Pulkkinen V, Kere J, Saavalainen P: Neuropeptide S receptor 1 expression in the intestine and skin - putative role in peptide hormone secretion. Neurogastroenterol Motil 2009.

11. Gottlieb DJ, O'Connor GT, Wilk JB: Genome-wide association of sleep and circadian phenotypes. BMC Med Genet 2007, 8(Suppl 1):S9.

12. Leonard SK, Dwyer JM, Sukoff Rizzo SJ, Platt B, Logue SF, Neal SJ, Malberg JE, Beyer CE, Schechter LE, Rosenzweig-Lipson S, Ring RH: Pharmacology of neuropeptide $S$ in mice: therapeutic relevance to anxiety disorders. Psychopharmacology (Berl) 2008, 197(4):601-611.

13. Bjarnadottir TK, Gloriam DE, Hellstrand SH, Kristiansson H, Fredriksson R, Schioth HB: Comprehensive repertoire and phylogenetic analysis of the $\mathrm{G}$ protein-coupled receptors in human and mouse. Genomics 2006, 88(3):263-273.

14. Xu YL, Reinscheid RK, Huitron-Resendiz S, Clark SD, Wang Z, Lin SH, Brucher FA, Zeng J, Ly NK, Henriksen SJ, de Lecea L, Civelli O: Neuropeptide $S$ : a neuropeptide promoting arousal and anxiolytic-like effects. Neuron 2004, 43(4):487-497.

15. Gupte J, Cutler G, Chen JL, Tian H: Elucidation of signaling properties of vasopressin receptor-related receptor 1 by using the chimeric receptor approach. Proc Natl Acad Sci USA 2004, 101(6):1508-1513.

16. Vendelin J, Pulkkinen V, Rehn M, Pirskanen A, Raisanen-Sokolowski A, Laitinen A, Laitinen LA, Kere J, Laitinen T: Characterization of GPRA, a novel G protein-coupled receptor related to asthma. Am J Respir Cell Mol Biol 2005, 33(3):262-270.

17. Ulloa-Aguirre $A$, Conn PM: Targeting of $G$ protein-coupled receptors to the plasma membrane in health and disease. Front Biosci 2009, 14:973-994.

18. Lefkowitz RJ: Seven transmembrane receptors: something old, something new. Acta Physiol (Oxf) 2007, 190(1):9-19.

19. Pulkkinen V, Majuri ML, Wang G, Holopainen $\mathrm{P}$, Obase $Y$, Vendelin J, Wolff H, Rytila P, Laitinen LA, Haahtela T, Laitinen T, Alenius H, Kere J, Rehn M: Neuropeptide S and G protein-coupled receptor 154 modulate macrophage immune responses. Hum Mol Genet 2006, 15(10):1667-1679.

20. Xu YL, Gall CM, Jackson VR, Civelli O, Reinscheid RK: Distribution of neuropeptide $S$ receptor mRNA and neurochemical characteristics of neuropeptide S-expressing neurons in the rat brain. The Journal of comparative neurology 2007, 500(1):84-102.

21. Allen IC, Pace AJ, Jania LA, Ledford JG, Latour AM, Snouwaert JN, Bernier V, Stocco R, Therien AG, Koller BH: Expression and function of NPSR1/GPRA in the lung before and after induction of asthma-like disease. $\mathrm{Am} J$ Physiol Lung Cell Mol Physiol 2006.

22. Zhu H, Perkins C, Mingler MK, Finkelman FD, Rothenberg ME: The role of neuropeptide $S$ and neuropeptide $S$ receptor 1 in regulation of respiratory function in mice. Peptides

23. Reinscheid RK, Xu YL, Okamura N, Zeng J, Chung S, Pai R, Wang Z, Civelli O: Pharmacological characterization of human and murine neuropeptide $\mathrm{s}$ receptor variants. J Pharmacol Exp Ther 2005, 315(3):1338-1345.
24. Bernier V, Stocco R, Bogusky MJ, Joyce JG, Parachoniak C, Grenier K, Arget M, Mathieu MC, O'Neill GP, Slipetz D, Crackower MA, Tan CM, Therien AG: Structure-function relationships in the neuropeptide $S$ receptor: molecular consequences of the asthma-associated mutation N107l. J Biol Chem 2006, 281(34):24704-24712.

25. Okamura N, Habay SA, Zeng J, Chamberlin AR, Reinscheid RK: Synthesis and pharmacological in vitro and in vivo profile of 3-oxo-1,1-diphenyltetrahydro-oxazolo[3,4-a]pyrazine-7-carboxylic acid 4-fluoro-benzylamide (SHA 68), a selective antagonist of the neuropeptide $\mathrm{S}$ receptor. J Pharmacol Exp Ther 2008, 325(3):893-901.

26. Livak KJ, Schmittgen TD: Analysis of relative gene expression data using real-time quantitative PCR and the 2(-Delta Delta $C(T))$ Method. Methods 2001, 25(4):402-408.

27. Vendelin J, Bruce S, Holopainen P, Pulkkinen V, Rytila P, Pirskanen A, Rehn M, Laitinen T, Laitinen LA, Haahtela T, Saarialho-Kere U, Laitinen A, Kere J: Downstream target genes of the Neuropeptide S-NPSR1 pathway. Hum Mol Genet 2006, 15:2923-2935.

28. Gautier L, Cope L, Bolstad BM, Irizarry RA: affy-analysis of Affymetrix GeneChip data at the probe level. Bioinformatics 2004, 20(3):307-315.

29. Smyth GK: Linear models and empirical bayes methods for assessing differential expression in microarray experiments. Stat Appl Genet Mol Biol 2004, 3:Article3.

30. Wirta V, Gry Björklund M, Klevebring D: The Kth-package for microarray data analysis. 2005 [http://www.Biotech.Kth.se/molbio/microarray].

31. Adner M, Larsson B, Safholm J, Naya I, Miller-Larsson A: Budesonide prevents cytokine-induced decrease of the relaxant responses to formoterol and terbutaline, but not to salmeterol, in mouse trachea. J Pharmacol Exp Ther 333(1):273-280.

32. Marchese A, Paing MM, Temple BR, Trejo J: G protein-coupled receptor sorting to endosomes and lysosomes. Annu Rev Pharmacol Toxicol 2008, 48:601-629.

33. Bruce S, Nyberg F, Melen E, James A, Pulkkinen V, Orsmark-Pietras $C$ Bergstrom A, Dahlen B, Wickman M, von Mutius E, Doekes G, Lauener R, Riedler J, Eder W, van Hage M, Pershagen G, Scheynius A, Kere J: The protective effect of farm animal exposure on childhood allergy is modified by NPSR1 polymorphisms. J Med Genet 2009, 46(3):159-167.

34. Orsmark-Pietras $C$, Melen E, Vendelin J, Bruce $S$, Laitinen A, Laitinen LA, Lauener R, Riedler J, von Mutius E, Doekes G, Wickman M, van Hage M, Pershagen G, Scheynius A, Nyberg F, Kere J: Biological and genetic interaction between tenascin $C$ and neuropeptide $S$ receptor 1 in allergic diseases. Hum Mol Genet 2008, 17(11):1673-1682.

35. Pulkkinen V, Haataja R, Hannelius U, Helve O, Pitkanen OM, Karikoski R, Rehn M, Marttila R, Lindgren CM, Hastbacka J, Andersson S, Kere J, Hallman M, Laitinen T: G protein-coupled receptor for asthma susceptibility associates with respiratory distress syndrome. Ann Med 2006, 38(5):357-366.

36. Okamura N, Hashimoto K, lyo M, Shimizu E, Dempfle A, Friedel S, Reinscheid RK: Gender-specific association of a functional coding polymorphism in the Neuropeptide $\mathrm{S}$ receptor gene with panic disorder but not with schizophrenia or attention-deficit/hyperactivity disorder. Prog Neuropsychopharmacol Biol Psychiatry 2007, 31(7):1444-1448.

37. Harper DG, Stopa EG, Kuo-Leblanc V, McKee AC, Asayama K, Volicer L, Kowall N, Satlin A: Dorsomedial SCN neuronal subpopulations subserve different functions in human dementia. Brain 2008, 131(Pt 6):1609-1617.

38. Bossard C, Souaze F, Jarry A, Bezieau S, Mosnier JF, Forgez P, Laboisse CL: Over-expression of neurotensin high-affinity receptor 1 (NTS1) in relation with its ligand neurotensin (NT) and nuclear beta-catenin in inflammatory bowel disease-related oncogenesis. Peptides 2007, 28(10):2030-2035.

39. McGee HS, Agrawal DK: TH2 cells in the pathogenesis of airway remodeling: regulatory $\mathrm{T}$ cells a plausible panacea for asthma. Immunol Res 2006, 35(3):219-232.

40. Miki-Hosokawa T, Hasegawa A, Iwamura C, Shinoda K, Tofukuji S, Watanabe Y, Hosokawa H, Motohashi S, Hashimoto K, Shirai M, Yamashita M, Nakayama T: CD69 Controls the Pathogenesis of Allergic Airway Inflammation. J Immunol 2009.

41. Wang ET, Sandberg R, Luo S, Khrebtukova I, Zhang L, Mayr C, Kingsmore SF, Schroth GP, Burge CB: Alternative isoform regulation in human tissue transcriptomes. Nature 2008, 456(7221):470-476.

42. Blencowe BJ: Alternative splicing: new insights from global analyses. Cell 2006, 126(1):37-47. 
43. Wong SK: G protein selectivity is regulated by multiple intracellular regions of GPCRs. Neurosignals 2003, 12(1):1-12

44. Miller WE, Houtz DA, Nelson CD, Kolattukudy PE, Lefkowitz RJ: G-proteincoupled receptor (GPCR) kinase phosphorylation and beta-arrestin recruitment regulate the constitutive signaling activity of the human cytomegalovirus US28 GPCR. J Biol Chem 2003, 278(24):21663-21671.

45. Richardson RM, Pridgen BC, Haribabu B, Snyderman R: Regulation of the human chemokine receptor CCR1. Cross-regulation by CXCR1 and CXCR2. J Biol Chem 2000, 275(13):9201-9208.

46. Suvorova ES, Gripentrog JM, Jesaitis AJ, Miettinen HM: Agonist-dependent phosphorylation of the formyl peptide receptor is regulated by the membrane proximal region of the cytoplasmic tail. Biochim Biophys Acta 2009, 1793(2):406-417.

\section{Pre-publication history}

The pre-publication history for this paper can be accessed here: http://www.biomedcentral.com/1471-2466/11/39/prepub

doi:10.1186/1471-2466-11-39

Cite this article as: Pietras et al:: The asthma candidate gene NPSR1 mediates isoform specific downstream signalling. BMC Pulmonary

Medicine 2011 11:39.

\section{Submit your next manuscript to BioMed Central} and take full advantage of:

- Convenient online submission

- Thorough peer review

- No space constraints or color figure charges

- Immediate publication on acceptance

- Inclusion in PubMed, CAS, Scopus and Google Scholar

- Research which is freely available for redistribution

Submit your manuscript at www.biomedcentral.com/submit 